\title{
Effect of immersion in various disinfectant solutions on the properties of a heat-cured acrylic resin
}

\author{
Efeito da imersão em diferentes soluções desinfetantes nas \\ propriedades de uma resina acrílica de termoativação
}

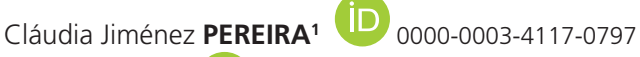 \\ Bruna GENARI² ID 0000-0002-6329-9543 \\ Vicente Castelo Branco LEITUNE2 ${ }^{2}$ iD 0000-0002-5415-1731 \\ Fabrício Mezzomo COLLARES ${ }^{2}$ iD 0000-0002-1382-0150 \\ Susana Maria Werner SAMUEL ${ }^{2}$ iD 0000-0001-5467-2636
}

\section{ABSTRACT}

Objective: The aim of the present study was to evaluate the influence, of immersion in different disinfectant solutions, on microhardness and surface roughness of a heat-cured acrylic resin. Methods: Specimens were immersed in distilled water, commercial vinegar for domestic use, sodium hypochlorite and hydrogen peroxide, for 150 hours or 300 hours $(n=10)$. After periods of immersion, Knoop microhardness and surface roughness were evaluated using a microhardness tester and a roughness tester, respectively. The data were analyzed using two-way ANOVA and Holm-Sidak, at a level of significance of $5 \%$. Results: The microhardness values ranged from $16.90 \pm 0.33$ to $17.80 \pm 0.51$ and roughness values from $0.05 \pm 0.01$ to $0.08 \pm 0.02$. There is no difference in microhardness and roughness between groups and times $(p>0.05)$. Conclusion: Within the limitations of this study, it is possible to conclude that vinegar and hydrogen peroxide, as alternative disinfectant solutions for acrylic resin devices, did not promote deleterious effects on microhardness and polishing of a heat-cured acrylic resin used for the fabrication of prostheses, neither in the medium term nor the long term.

Indexing terms: Acetic acid. Complete denture. Disinfection.

\section{RESUMO}

Objetivo: Avaliar a influência da imersão em diferentes soluções desinfetantes na microdureza e rugosidade de uma resina acrilica de termoativação. Métodos: Corpos de prova de resina acrílica termopolimerizável foram imersos em água destilada, vinagre comercial de uso doméstico, hipoclorito de sódio e peróxido de hidrogênio, por períodos de $150 \mathrm{~h}$ ou $300 \mathrm{~h}$ ( $\mathrm{n=10}$ ). A microdureza Knoop e a rugosidade superficial dos corpos de prova foram avaliadas com o uso de microdurômetro e rugosímetro, respectivamente. Os dados foram analisados com o teste análise de variância a dois critérios e Holm-Sidak, com nível de significância de 5\%. Resultados: Os

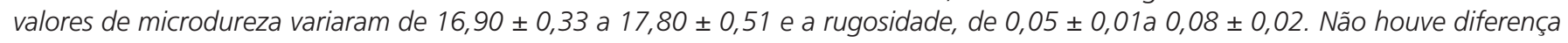

\footnotetext{
$\nabla \nabla v$

1 Universidad de la Republica, Faculdade de Odontologia, Cátedra de Oclusión y Prostodoncia. Montevideo, Uruguay.

2 Universidade Federal do Rio Grande do Sul, Faculdade de Odontologia, Laboratório de Materiais Dentários. Rua Ramiro Barcelos, 2492, 90035-003, Porto Alegre, RS, Brasil. Correspondência para / Correspondence to: SMW SAMUEL. E-mail: <susana.samuel@ufrgs.br>.

Pereira CJ, Genari B, Leitune VCB, Collares FM, Samuel SMW. Effect of immersion in various disinfectant solutions on the properties of a heat-cured acrylic resin. RGO, Rev Gaúch Odontol. 2019;67:e20190052. http://dx.doi.org/10.1590/1981-86372019000523090
} 
nos resultados de microdureza e rugosidade entre os grupos e tempos ( $p>0.05$ ). Conclusão: Dentro das limitações do estudo, é possível concluir que a utilização de vinagre ou de peróxido de hidrogênio, como alternativas para a desinfecção de resina acrílica, não provocam efeitos deletérios na dureza e no polimento da resina acrílica termoativada utilizada para confecção de próteses, nem a médio nem a longo prazo.

Termos de indexação: Ácido acético. Prótese total. Desinfecção.

\section{INTRODUCTION}

Denture stomatitis, characterized by inflamed and erythematous mucosa that is covered by the denture, is the most common form of oral candidiasis [1]. Prevalence varies between approximately $20 \%$ and $80 \%$ among complete denture users [2,3]. Despite being a multifactorial disease, the colonization of the inner surface of the denture by Candida albicans is one of its main etiological factors [4]. The contaminated denture acts as a reservoir of microorganisms and starts to act as an agent of progression, maintenance and recurrence of the disease.

The porous nature of acrylic resins makes it difficult to clean them mechanically, as it is ineffective in controlling infections in dentures. Therefore, immersion in disinfectant solutions has become a procedure adopted to supplement the cleaning of prosthetic surfaces [5-7]. Of these solutions, glutaraldehyde and sodium hypochlorite are the most commonly used [8]. However, these solutions possess a number of disadvantages, such as the toxicity of glutaraldehyde, corrosive action on metals, irritant effect on the skin and the staining of tissue by sodium hypochlorite $[8,9]$. There is, therefore, a need to find alternative solutions with disinfecting capacity, without affecting the material's properties.

Vinegar is an easily accessible, low-cost acetic acid solution with low toxicity, and proven effectiveness against some microorganisms, such as Candida albicans $[8,10]$. This solution is considered to be a promising disinfectant in medicine and the food industry $[8,11]$. However, more studies are needed to evaluate the effect of immersion in vinegar on the microhardness and roughness of acrylic resins.

Therefore, the aim of the present study was to evaluate the influence of immersion in different disinfectants on the microhardness and roughness of a heat-cured acrylic resin.

\section{METHODS}

Eighty heat-cured, acrylic resin specimens (Melioden ${ }^{\circledR}$ Heat Cure, Heraeus Kultzer, Hanau, Germany) were fabricated, with dimensions of $2.5 \mathrm{~cm} \times 1.0 \mathrm{~cm} \times 0.4 \mathrm{~cm}$. The specimens were polymerized in a metal kiln according to the manufacturer's recommendations. The polymerization cycle consisted of heating to $100^{\circ} \mathrm{C}$ the water in the container used for the heat-curing, turning off the flame, placing the kiln in water and leaving it for 15 minutes. Afterwards, the heat was once again turned on until it reached $100^{\circ} \mathrm{C}$ and the kiln was kept in place for a further 20 minutes [12]. The microwave remained immersed in water until it had cooled to room temperature. After they had fully cooled, the specimens were finished and polished (Aropol 2v, Arotec, Cotia, Brazil) using 400, 600 and 1200 grain wet sandpaper and a felt disc impregnated with a solution of aluminum oxide $(0.5 \mu \mathrm{m})$ for 3 minutes with each sander and disc. The specimens were divided at random into 8 groups according to the disinfectant and the length of time immersed $(n=10)$.

\section{Immersion in disinfectant solutions}

Each specimen was immersed in $10 \mathrm{~mL}$ of distilled water (control), vinegar (Gamberoni, Villa Lima, Libertad, Uruguay), 1\% sodium hypochlorite (Milton solution, lodontosul, Porto Alegre, Brazil) and V10 hydrogen peroxide (from a compounding pharmacy). The samples were maintained in solution for 150 hours and 300 hours, without interruption, in closed containers. None of the solutions was replaced during this period. After immersion, the specimens were washed in distilled water and dried with absorbent paper.

\section{Knoop microhardness}

The Knoop microhardness of the specimens was obtained using an automatic microhardness tester (HMV2, Shimadzu, Quito, Japan) with a load of $25 \mathrm{~g}$, for 10 seconds. The microhardness values were obtained by means of five measurements taken at the surface of each specimen. The calculation of the Knoop microhardness value was obtained using the following equation (1): 


$$
\mathrm{KHN}=\left[(14228 \mathrm{c}) /\left(\mathrm{d}^{2}\right)\right]
$$

where $\mathbf{1 4 2 2 8}$ is the value of a constant, $\mathrm{c}$ is the load applied in grams, and $d$ is the length of the longest diagonal of the consequent diamond shape, in $\mu \mathrm{m}$.

\section{Roughness}

The roughness was computed using a roughness meter (SJ-201, Mitutoyo, Kanagawa, Japan) in scan mode, considering the parameter $\mathrm{Ra}$ and the result expressed in $\mu \mathrm{m}$. Five readings were taken for each specimen and the final measurement was the arithmetic mean of these measurements.

\section{Analysis of results}

The normality of the values obtained was tested via the Kolmogorov-Smirnov test. The two-way ANOVA test was used and, where there was a difference, the Holm-Sidak multiple comparison test was applied. The level of significance was $5 \%$.

\section{RESULTS}

The microhardness results are displayed in table 1 , ranging from $16.9 \pm 0.33$ to $17.80 \pm 0.51$. There was no statistical significance between the groups and times $(p=0.52)$.

For the surface roughness test (table 1), values ranged from $0.05 \pm 0.01$ to $0.08 \pm 0.02 \mu \mathrm{m}$. There was no significant statistical difference between the disinfectant solutions and times $(p=0.95)$.

\section{DISCUSSION}

The immersion of acrylic resin prosthetic appliances in solutions can be performed using a homemade disinfection procedure. However, these disinfectants interfere with the properties of the polymer material $[13,14]$. With this in mind, the present study evaluated the influence of immersion in different disinfectants on the microhardness and roughness of a heat-cured resin. These properties, after immersion in vinegar and hydrogen peroxide, were no different from distilled water, used as the control, and sodium hypochlorite, which is regarded as the paradigm in disinfection.

The immersion of the acrylic resin for 150 and 300 hours simulates five minutes a day in contact with disinfectant for periods of five and ten years, respectively. Considering that the immersion was continuous, the challenge is harder than that promoted by intermittent exposure. Five years equates to the period of use recommended for an acrylic resin denture and ten years represents the extrapolation of the period of use [14]. Thus, the acrylic resin properties were retained after immersion in disinfectant solutions in the present study, for a period of time corresponding to the useful life of the dentures. Among various other aspects, such as occlusion and the condition of the patient's residual ridge, the properties of acrylic resin have a direct impact on the useful life of the denture, since adaptation and contamination are aspects that are relevant to longevity and are linked to the material's performance [15].

A variety of active agents have been used for the chemical disinfection of the denture base. Sodium hypochlorite is a solution used as the gold standard due to its comprehensive effectiveness. Nevertheless, it does

Table 1. Knoop microhardness and roughness in micrometers (mean \pm standard deviation) of the acrylic resin after two periods of immersion in different solutions.

\begin{tabular}{lcccc}
\hline \multirow{2}{*}{ Solutions } & \multicolumn{2}{c}{ Microhardness } & \multicolumn{2}{c}{ Surface roughness } \\
\cline { 2 - 4 } & $150 \mathrm{~h}$ & $300 \mathrm{~h}$ & $150 \mathrm{~h}$ & $300 \mathrm{~h}$ \\
\hline Distilled water & $17.50 \pm 0.62^{\mathrm{Aa}}$ & $17.40 \pm 0.69^{\mathrm{Aa}}$ & $0.06 \pm 0.02^{\mathrm{Aa}}$ & $0.07 \pm 0.04^{\mathrm{Aa}}$ \\
Vinegar & $17.80 \pm 0.42^{\mathrm{Aa}}$ & $17.40 \pm 0.48^{\mathrm{Aa}}$ & $0.06 \pm 0.02^{\mathrm{Aa}}$ & $0.06 \pm 0.01^{\mathrm{Aa}}$ \\
Sodium hypochlorite & $17.80 \pm 0.51^{\mathrm{Aa}}$ & $17.20 \pm 0.46^{\mathrm{Aa}}$ & $0.08 \pm 0.02^{\mathrm{Aa}}$ & $0.08 \pm 0.01^{\mathrm{Aa}}$ \\
Hydrogen peroxide & $17.20 \pm 0.35^{\mathrm{Aa}}$ & $16.90 \pm 0.33^{\mathrm{Aa}}$ & $0.05 \pm 0.01^{\mathrm{Aa}}$ & $0.05 \pm 0.01^{\mathrm{Aa}}$ \\
\hline
\end{tabular}

Note: Values followed by different lower case letters on the same line demonstrate a statistically significant difference ( $p<0.05)$. Uppercase letters in the same column are statistically different from one another $(p<0.05)$. 
possess undesirable side effects such as corrosive action on metals, the staining of the dentures and an irritant effect on the skin $[8,9]$. Hydrogen peroxide, on the other hand, possesses antimicrobial action on account of its alkaline characteristics [16]. Harmful effects of color change and reduced flexural strength may occur with the use of hydrogen peroxide [17]. Finally, vinegar is an easily accessible, low-cost solution whose effectiveness against Candida albicans, Streptococcus mutans, Staphylococcus aureus, Escherichia coli and Bacillus subtili is well-established $[8,10]$. With regard to $C$. albicans, the main organism involved in denture stomatitis, vinegar was no different from sodium hypochlorite and chlorhexidine, and outperformed sodium perborate based tablets [9]. Being an acid, its action is promoted by the dissolution of lime deposits and protein denaturation [10].

Immersion in solutions may result in the material dissolving, caused by polymer degradation [13]. Polymer exposure to a solution results in hydrolytic degradation arising from the chemical interaction between the solution and the organic matrix in the free spaces between the chains in the polymer system $[13,14]$. Moreover, the active agents could result in accelerated chemical degradation [18]. However, as observed in a previous study [7], agents with acidic and alkaline action did not result in an alteration superior to that of the hydrolytic solution. This can be explained, in the case of hydrogen peroxide, by the limited diffusion of the hydroxyl radicals [17].

The effect of the degradation of the polymer matrix is initially noted through the increase in surface roughness [19-21], which facilitates the colonization of microbes [4]. In the present study, immersion in disinfectant solutions did not result in an increase in roughness, as observed in previous studies $[23,24]$. Moreover, in the present study, roughness after immersion, over the different periods of time, did not exceed the threshold of $0.2 \mu \mathrm{m}$, which is the tolerable limit for preventing Candida albicans adhesion $[24,25]$. The roughness of acrylic resin after immersion in vinegar or oxygenated water, whether for 150 or 300 hours, showed no difference in comparison with immersion in distilled water or sodium hypochlorite for the same time periods, remaining at values below $0.2 \mu \mathrm{m}$.

In addition to the relation with disinfectant solutions, the mechanical and rheological properties depend on the density of the cross-links of the polymer material. The polymer matrix varies according to the type and composition of the acrylic resin, and may contain pigments, cross-linking agents, load and fibers [26]. Heat-curable acrylic resin with a cross-linking agent, as used in the present study, favored the maintenance of microhardness and polishing.

Within the limitations of the study, it may be concluded that the use of vinegar or hydrogen peroxide, as alternative agents for disinfecting acrylic resin, does not cause harmful effects on hardness or on the polishing of heat-cured acrylic resin used in the fabrication of dentures, neither in the medium term nor the long term.

\section{Collaborators}

CJ PEREIRA, study design, performed the tests, manuscript draft. B GENARI, performed the tests, manuscript draft. VCB LEITUNE, study design, data analysis, final review of manuscript. FM COLLARES, study design, final review of manuscript. SMW SAMUEL, study design, manuscript draft, final review of manuscript.

\section{REFERENCES}

1. Sullivan DJ, Moran GP, Pinjon E, Al-Mosaid A, Stokes C, Vaughan $C$, et al. Comparison of the epidemiology, drug resistance mechanisms, and virulence of Candida dubliniensis and Candida albicans. FEMS Yeast Res. 2004;4(4-5):369-76. http://dx.doi.org/10.1016/S1567-1356(03)00240-X

2. Bianchi CM, Bianchi HA, Tadano T, Paula CR, HoffmannSantos HD, Leite Jr DP, Hahn RC. Factors related to oral candidiasis in elderly users and non-users of removable dental prostheses. Rev Inst Med Trop Sao Paulo. 2016;58:17. http:// dx.doi.org/10.1590/S1678-9946201658017

3. Emami E, Séguin J, Rompré PH, de Koninck L, de Grandmont $P$, Barbeau J. The relationship of myceliated colonies of Candida albicans with denture stomatitis: an in vivo/in vitro study. Int J Prosthodont. 2007;20(5):514-20.

4. Gendreau L, Loewy ZG. Epidemiology and etiology of denture stomatitis. J Prosthodont. 2011;20(4):251-60. http://dx.doi. org/10.1111/j.1532-849X.2011.00698.x

5. Asad T, Watkinson AC, Huggett R. The effects of various disinfectant solutions on the surface hardness of an acrylic resin denture base material. Int J Prosthodont. 1993;6(1):9-12.

6. da Silva FC, Kimpara ET, Mancini MN, Balducci I, Jorge AO, Koga-Ito CY. Effectiveness of six different disinfectants on removing five microbial species and effects on the topographic characteristics of acrylic resin. J Prosthodont. 2008;17(8):627-33. http://dx.doi.org/10.1111/j.1532-849X.2008.00358.x

7. Sun HW, Feigal RJ, Messer HH. Cytotoxicity of glutaraldehyde and formaldehyde in relation to time of exposure and concentration. Pediatr Dent. 1990;12(5):303-7.

8. Kumar MN, Thippeswamy HM, Raghavendra Swamy KN, Gujjari AK. Efficacy of commercial and household denture 
cleansers against Candida albicans adherent to acrylic denture base resin: an in vitro study. Indian J Dent Res. 2012;23(1):39-42. http://dx.doi.org/10.4103/0970-9290.99036

9. Nascimento MS, Silva N, Catanozi MPLM, Silva KC. Avaliação Comparativa de Diferentes Desinfetantes na Sanitização de Uva. Braz J Food Technol. 2003;6(1):63-8.

10. Jerolimov $\vee$, Krhen J, Besić J. The role of residual monomer in PMMA powder and methods of polymerization in the finding of residual monomer in poly(methylmethacrylate) denture base. Acta Stomatol Croat. 1991;25(1):17-23.

11. Ferracane JL. Hygroscopic and hydrolytic effects in dental polymer networks. Dent Mater. 2006;22(3):211-22. http:// dx.doi.org/10.1016/j.dental.2005.05.005

12. Neppelenbroek KH, Kuroishi E, Hotta J, Marques VR, Moffa EB, Soares S, Urban VM. Surface properties of multilayered, acrylic resin artificial teeth after immersion in staining beverages. J Appl Oral Sci. 2015;23(4):376-82. http://dx.doi. org/10.1590/1678-775720150054

13. Kimoto S, Kimoto K, Murakami H, Gunji A, Ito N, Kawai Y. Survival analysis of mandibular complete dentures with acrylic-based resilient liners. Gerodontology. 2013;30(3):187-93. http://dx.doi.org/10.1111/j.1741-2358.2012.00658.x

14. Kanno T, Nakamura K, Ikai H, Hayashi E, Shirato M, Mokudai $\mathrm{T}$, et al. Novel denture-cleaning system based on hydroxyl radical disinfection. Int J Prosthodont. 2012;25(4):376-80.

15. Nakahara T, Harada A, Yamada Y, Odashima Y, Nakamura K, Inagaki $R$, et al. Influence of a new denture cleaning technique based on photolysis of $\mathrm{H} 2 \mathrm{O} 2$ on the mechanical properties and color change of acrylic denture base resin. Dent Mater J. 2013;32(4):529-36.

16. Lee SY, Huang HM, Lin CY, Shih YH. Leached components from dental composites in oral simulating fluids and the resultant composite strengths. J Oral Rehabil 1998;25(8):575-88. http://dx.doi.org/10.1046/j.1365-2842.1998.00284.x

17. de Oliveira JC, Aiello G, Mendes B, Urban VM, Campanha $\mathrm{NH}$, Jorge $\mathrm{JH}$. Effect of storage in water and thermocycling on hardness and roughness of resin materials for temporary restorations. Materials Research. 2010;13(3). http://dx.doi. org/10.1590/S1516-14392010000300013
18. Arévalo E, Maldonado $V$, Bizarro S. Análisis microscópico de la adherencia de Candida albicans in vitro sobre resina acrílica utilizada para bases de dentaduras procesada con tres diferentes técnicas. Rev Odontol Mex. 2006;10(4).

19. Azevedo A, Machado AL, Vergani CE, Giampaolo ET, Pavarina AC, Magnani R. Effect of disinfectants on the hardness and roughness of reline acrylic resins. J Prosthodont. 2006;15(4):235-42. http://dx.doi.org/10.1111/j.1532-849X. 2006.00112.x

20. Azevedo A, Machado AL, Vergani CE, Giampaolo ET, Pavarina AC. Hardness of denture base and hard chair-side reline acrylic resins. J Appl Oral Sci. 2005;13(3):291-5. http://dx.doi. org/10.1590/S1678-77572005000300017

21. Ural Ç, Şanal FA, Cengiz S. Effect of different denture cleansers on surface roughness of denture base materials. J Adv Prosthodont. 2016;8(5): 333-338.

22. Bollen CM, Lambrechts P, Quirynen M. Comparison of surface roughness of oral hard materials to the threshold surface roughness for bacterial plaque retention: a review of the literature. Dent Mater. 1997;13(4):258-69.

23. Rao DC, Kalavathy N, Mohammad HS, Hariprasad A, Kumar $C R$. Evaluation of the surface roughness of three heatcured acrylic denture base resins with different conventional lathe polishing techniques: A comparative study. J Indian Prosthodont Soc. 2015;15(4):374-80. http://dx.doi.org/10.41 03/0972-4052.164910

24. Rodrigues SB, Leitune VCB, Hashizume LN, Samuel SMW, Collares FM. Polímero de MMA para base de dentadura com a adição de subnitrato de bismuto. RFO. 2014;19(2):166-71. http://dx.doi.org/10.5335/rfo.v19i2.3641

25. Jaikumar RA, Karthigeyan S, Ali SA, Naidu NM, Kumar RP, Vijayalakshmi K. Comparison of flexural strength in three types of denture base resins: An in vitro study. J Pharm Bioallied Sci. 2015;7(Suppl 2):S461-4. http://dx.doi.org/10.4103/0975-74 06.163505 